\title{
Effects on maternal and fetal steroid concentrations of induction of parturition in the sheep by inhibition of 3ß-hydroxysteroid dehydrogenase
}

\author{
Marian Silver \\ Physiological Laboratory, Cambridge CB2 3EG, U.K.
}

\begin{abstract}
Summary. Changes in circulating steroid hormones, the incidence of myometrial contractions, and the onset of labour were all monitored after administration of the $3 \beta$ hydroxysteroid dehydrogenase inhibitor, epostane, to chronically catheterized ewes and fetuses near term. In all animals the drug induced delivery $33-36 \mathrm{~h}$ after injection or infusion into the ewe with the birth of live healthy lambs which showed normal subsequent development.

Epostane induced immediate, permanent falls in both maternal and fetal plasma progesterone concentrations, accompanied by increased PGF metabolite concentrations in the uterine vein beginning $15 \mathrm{~min}$ after treatment. Of the other hormonal changes observed, the most striking was the pronounced drop in both maternal and fetal plasma cortisol. In the fetus this fall was followed by increasing concentrations of circulating ACTH which eventually restored the cortisol levels. By $12-24 \mathrm{~h}$ after epostane a substantial overshoot had occurred and at $27-30 \mathrm{~h}$ the fetal plasma cortisol concentrations were as high as those seen during normal parturition at term. No significant changes in maternal plasma oestradiol-17 $\beta$ could be detected after epostane treatment or during labour. The incidence of slow myometrial contractions increased significantly during the second 3-h period after epostane, although their duration did not change. Contraction patterns typical of first stage labour were seen from 20 to $24 \mathrm{~h}$. These results show that epostane may be used as a safe, predictable inducing agent in sheep if given 6-10 days before term; the lambs showed no signs of prematurity despite their lowered plasma cortisol concentrations which persisted for some hours before labour was induced.
\end{abstract}

Keywords: epostane; parturition; sheep; $3 \beta$-hydroxysteroid dehydrogenase; cortisol

\section{Introduction}

Inhibitors of $3 \beta$-hydroxysteroid dehydrogenase ( $3 \beta-\mathrm{HSD})$ reduce the production of progesterone from pregnenolone and are therefore potentially useful in the termination of gestation or induction of parturition near term. Initial studies on rats and monkeys showed that such drugs (trilostane and epostane) were orally active as interceptive agents at comparatively high dose rates although they also affected adrenocorticosteroid activity (Potts et al., 1978; Shane et al., 1979; Creange et al., 1981). Tests on pregnant sheep in late gestation showed that a single intravenous injection of trilostane caused a rapid and prolonged drop in circulating progesterone although labour was not invariably induced (Taylor et al., 1982; Jenkin \& Thorburn, 1984). Ledger et al. (1985) reported that epostane also caused cervical ripening in the pregnant ewe near term, at the time of maximum reduction in progesterone, but the incidence of successful labour was not investigated. In the mare near term epostane caused only a temporary fall in progesterone and failed to induce delivery (Fowden \& Silver, 1987). 
The extent to which trilostane or epostane can cross the sheep placenta and affect fetal steroid production is uncertain. Fetal plasma progesterone concentrations were reduced after epostane treatment in the mare but no systematic observations were made on fetal steroid values (Fowden $\&$ Silver, 1987). Silver \& Fowden (1988) have shown that epostane causes an immediate reduction in both maternal and fetal steroid concentrations in the sow, suggesting a rapid placental transfer of the drug in this species. In view of the essential role played by the fetal pituitary-adrenal axis in the initiation of parturition in the ewe (Liggins et al., 1973) it seemed important to determine whether the normal pre-partum rise in fetal plasma cortisol was affected by $3 \beta-H S D$ inhibition. Disturbance of these prenatal changes might perhaps explain failure to induce parturition in some ewes despite low maternal plasma progesterone concentrations (Taylor et al., 1982; Jenkin \& Thorburn, 1984). The present experiments were therefore undertaken (1) to examine the effects of $3 \beta$-HSD inhibition in the fetus, and (2) to determine whether epostane, administered within 10 days of term, could be used as an inducing agent in sheep, with the delivery of viable lambs. A preliminary account of the last part of the study has been published (Silver, 1987).

\section{Materials and Methods}

\section{Animals}

Pregnant Welsh Mountain sheep at 126-130 days of gestation were provided with intravascular fetal and maternal catheters and an intrauterine balloon by techniques described previously (Comline \& Silver, 1972; Fowden \& Silver, 1983 , 1985). The animals were sampled 3 times per week after surgery to maintain catheter patency and check on fetal wellbeing. Tests with the 33-HSD inhibitor were carried out at 137-139 days (Group 1 ewes, N = 5) and at 141-142 days (Group 2, N = 5); a control group was tested with vehicle only at 136-139 days and received no further treatment (Group $C, N=4$ ). An additional group of 12 pregnant ewes (Group 3) was used at 139-142 days to test the

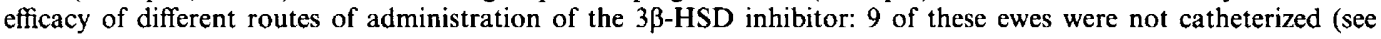
Table 1).

\section{Experimental procedures}

Epostane administration. Epostane (4,5-epoxy-17-hydroxy-4,17-dimethyl-3-oxoandrostane-2-carbonitrile; Win 32729, Sterling-Winthrop, Guildford, U.K.) was dissolved in ethanol $(10 \mathrm{mg} / \mathrm{ml})$ and infused into the maternal femoral vein over about $30 \mathrm{~min}$ at a rate of $0.2 \mathrm{ml} / \mathrm{min}$ in Groups 1 and 2 . The total dose per ewe $(50 \mathrm{mg})$ was approximately $1-1 \cdot 3 \mathrm{mg} / \mathrm{kg}$ body weight. In addition to Group $\mathrm{C}$ ewes, 5 animals were infused with ethanol alone $3-4$ days before the epostane test.

In Group 3 ewes the following modes of epostane administration were tested: $50 \mathrm{mg}$ epostane were dissolved in $0.5 \mathrm{ml}$ dimethyl sulphoxide (DMSO) or suspended in physiological saline $(0.9 \% \mathrm{w} / \mathrm{v} \mathrm{NaCl})$ and injected i.m. Alternatively, $100 \mathrm{mg}$ epostane were given orally in about $2 \mathrm{ml}$ water.

Intrauterine pressure recording. Changes in intrauterine pressure were recorded from the saline-filled balloon in the allantoic cavity, connected to a pressure transducer and multichannel recorder. Recordings were made every $2-3$ days for $34 \mathrm{~h}$ and for $4-6 \mathrm{~h}$ on the day preceding the epostane test. Uterine activity was monitored throughout the day of the experiment $(9-12 h)$ and continued throughout the following day until the second stage of labour was clearly established.

Blood sampling. Samples from ewes in Groups 1 and 2 were taken from the maternal femoral artery and uterine vein $(2-3 \mathrm{ml})$ and from the fetal femoral artery $(1-1.5 \mathrm{ml})$ on the day before the experiment and at the following times before and after infusion of epostane or ethanol alone: $-60,-30,0,15,30,60$ and $90 \mathrm{~min}$ and then hourly until $6 \mathrm{~h}$. In the epostane-treated ewes samples were taken at 12 and $24 \mathrm{~h}$ and thereafter at 3-5-h intervals until parturition occurred. In 3 animals in Group 3 the same maternal sampling protocol was followed. The remainder were not sampled regularly although a jugular vein sample was taken before the epostane administration to check the plasma progesterone concentration at the time of the test.

Treatment of samples. The blood was placed in chilled EDTA-containing tubes and centrifuged immediately at $4^{\circ} \mathrm{C}$; the supernatant was stored at $-20^{\circ} \mathrm{C}$ until assay. A small volume of blood $(0 \cdot 2 \mathrm{ml})$ was retained for measurement of $\mathrm{pH}, \mathrm{O}_{2}$ saturation and haemoglobin on each fetal sample. Similar measurements were made on maternal arterial samples at intervals during the experiment.

\section{Hormone assays}

Plasma concentrations of cortisol, progesterone and prostaglandin F metabolite (PGFM) were determined by using radioimmunoassay methods which have been described and validated previously for sheep in this laboratory (Barnes et al., 1978; Robinson et al., 1983; Fowden \& Silver, 1983). The sensitivities of these assays (i.e. twice the 
reagent blank) were: $20-30 \mathrm{pg}$ for cortisol and progesterone and $10-30 \mathrm{pg}$ for PGFM. The interassay coefficients of variation were: $7.0 \%$ (cortisol), $7.9 \%$ (progesterone) and $11.0 \%$ (PGFM). Immunoreactive ACTH in the fetal plasma was determined using an Immunonuclear test kit (RIA UK Ltd, Washington, Tyne \& Wear, U.K.) standardized against $\mathrm{ACTH}_{1-24}$ WHO standard (no. 74/955). The sensitivity of the assay was $10-20 \mathrm{pg}$. Addition of exogenous $\mathrm{ACTH}_{1-24}$ to stripped fetal plasma in the range $0-250 \mathrm{pg} / \mathrm{ml}$ gave the following relationship $y=0.99 x+1.83$ ( $r=0.99, P<0.01, n=10$ ), where $y=$ measured and $x=$ added ACTH, minus the plasma blank. The inter-assay coefficient of variation over the range $40-200 \mathrm{pg}$ was $9-10 \%$, which was similar to values given by the manufacturers for human plasma. Because of the expense of the ACTH assay kit only a few fetal samples were assayed. Oestradiol$17 \beta$ was assayed by RIA using the procedure described previously (Barnes et al., 1978). The oestradiol antiserum (Steranti, St Albans, U.K.) had the following cross-reactions: $0.32 \%$ with oestradiol- $17 \alpha, 0.81 \%$ with oestrone, $0.17 \%$ with oestriol and $<0.03 \%$ with other steroids including androstenedione. Addition of oestradiol standard to stripped ovine plasma in the range $20-500 \mathrm{pg} / \mathrm{ml}$ gave the following relationship $y=1.02 x-0.55(r=0.99, n=10$, $P<0.01$ ) where $x=$ added and $y=$ measured oestradiol. The sensitivity of the assay was $5-10 \mathrm{pg} / \mathrm{ml}$ and the interassay coefficient of variation was $10 \cdot 4 \%$.

\section{Statistical analyses}

Mean \pm s.e.m. values are given throughout and statistical analyses of the data were carried out using the conventional Student's $t$ test or the paired $t$ test according to the methods of Snedecor \& Cochrane (1967).

\section{Results}

\section{Effect of epostane on the induction of labour}

Table 1 shows the outcome of pregnancy in each of the different groups treated with epostane. Labour was successfully induced in every animal irrespective of the amount or mode of administration of the drug, the proximity to full term or whether the animals had undergone surgery 10-14 days previously. Parturition occurred between 30 and $40 \mathrm{~h}$ after treatment, and there was no significant difference between the injection-to-delivery interval in the different groups. All lambs were viable and showed no signs of prematurity; birth weights (Table 1) were within the range for their gestational age (Silver, 1981) and their subsequent growth was normal.

Table 1. Effect of different modes of administration of epostane on induction of delivery in the ewe

\begin{tabular}{|c|c|c|c|c|c|c|}
\hline \multirow[b]{2}{*}{ Group } & \multirow{2}{*}{$\begin{array}{l}\text { Gestational } \\
\text { age (days) }\end{array}$} & \multirow{2}{*}{$\begin{array}{l}\text { No. of } \\
\text { ewes }\end{array}$} & \multicolumn{2}{|c|}{ Epostane } & \multirow{2}{*}{$\begin{array}{c}\text { Mean } \\
\text { injection- } \\
\text { delivery } \\
\text { interval }(\mathrm{h})\end{array}$} & \multirow{2}{*}{$\begin{array}{l}\text { Mean } \\
\text { wt of } \\
\text { lambs } \\
(\mathrm{kg})\end{array}$} \\
\hline & & & Dose & Route & & \\
\hline \multicolumn{7}{|c|}{ Catheterized } \\
\hline $\mathrm{C}$ & $136-139$ & 4 & Ethanol only & i.v.* & $-\uparrow$ & $2.8 \pm 0.3$ \\
\hline II & $141-142$ & 5 & $\begin{array}{l}50 \mathrm{mg} \text { in } 2 \mathrm{ml} \\
\text { ethanol }\end{array}$ & i.v.* & $33 \cdot 1 \pm 2 \cdot 2$ & $2.7 \pm 0.3$ \\
\hline I & $137-139$ & 5 & $\begin{array}{l}50 \mathrm{mg} \text { in } 2 \mathrm{ml} \\
\text { ethanol }\end{array}$ & i.v.* & $33.4 \pm 1.2$ & $2.6 \pm 0.2$ \\
\hline III & $139-141$ & 3 & $\begin{array}{l}50 \mathrm{mg} \text { in } 0.5 \mathrm{ml} \\
\text { DMSO }\end{array}$ & i.m. & $34 \cdot 3 \pm 2 \cdot 5$ & $2.5 \pm 0.3$ \\
\hline $\begin{array}{l}\text { Not cat } \\
\text { III }\end{array}$ & $139-141$ & 5 & $\begin{array}{l}50 \mathrm{mg} \text { in } 0.5 \mathrm{ml} \\
\text { DMSO }\end{array}$ & i.m. & $36.8 \pm 1.9$ & $2 \cdot 8 \pm 0.1$ \\
\hline III & $139-141$ & 2 & $\begin{array}{l}50 \mathrm{mg} \text { in } 2 \mathrm{ml} \\
\text { saline }\end{array}$ & i.m. & 36,40 & $2 \cdot 0,2 \cdot 9$ \\
\hline III & $139-142$ & 2 & $100 \mathrm{mg}$ & oral & 36,42 & $2 \cdot 2,3 \cdot 1$ \\
\hline
\end{tabular}

*Over 30 min.

$\dagger$ Delivered at $145 \pm 1$ day (term $=145-149$ days). 


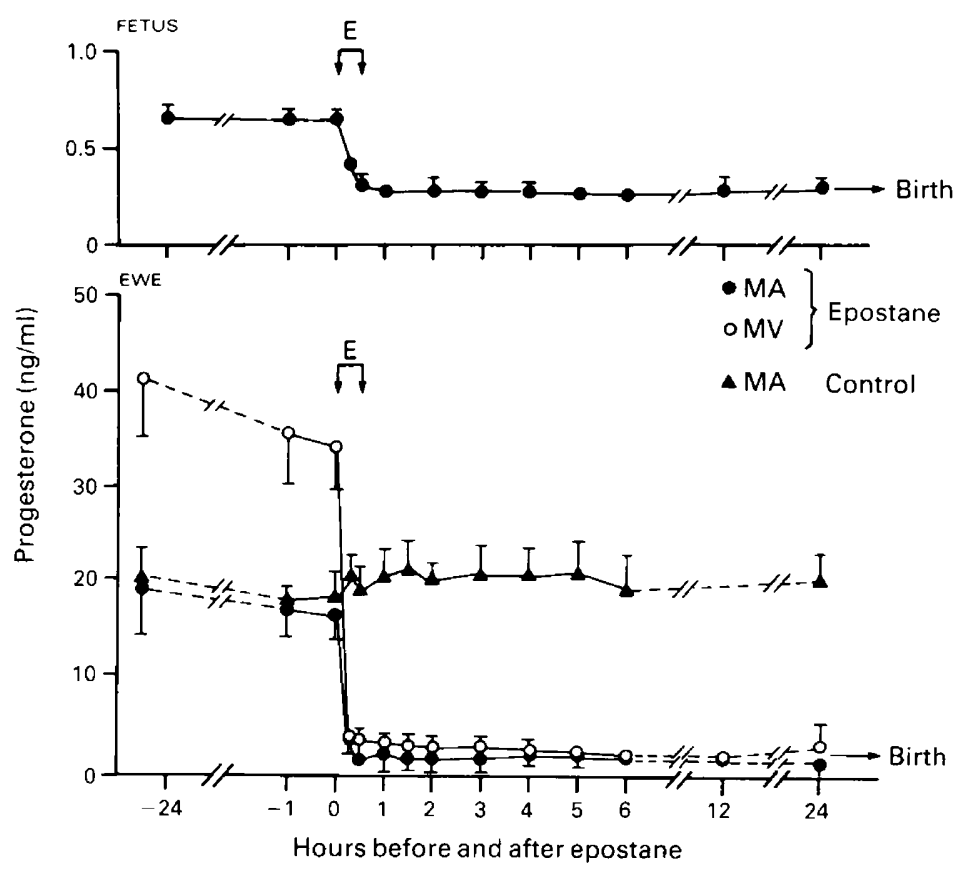

Fig. 1. Effect of epostane (arrows) on mean ( \pm s.e.) plasma progesterone concentrations in fetuses $(N=6)$ and mothers $(N=10)$. $M A=$ maternal arterial; $M V=$ uterine venous values. Maternal arterial values $(\Delta)$ during control infusion of ethanol were obtained in 5 ewes.

\section{Changes in plasma progesterone after epostane treatment}

Figure 1 shows the mean plasma concentrations of progesterone in the maternal artery and uterine vein before and after epostane administration, compared with values in the control experiments. There was no difference in the response in Groups 1 and 2 and the data have therefore been combined. A significant drop in maternal progesterone was seen $15 \mathrm{~min}$ after the onset of infusion of the drug and the large preinfusion venous-arterial (V-A) difference in progesterone $(17 \cdot 6 \pm 3 \cdot 1 \mathrm{ng} / \mathrm{ml})$ fell to insignificant levels within $0.5 \mathrm{~h}$. Maternal progesterone concentrations remained low throughout the remainder of gestation. When epostane was given intramuscularly as a single dose in DMSO (Group 3 ), the fall in maternal plasma progesterone showed the same time course and the values of $1-2 \mathrm{ng} / \mathrm{ml}$, obtained after $6 \mathrm{~h}$, were similar to those after intravenous infusion of the drug. No changes in maternal progesterone concentrations were seen in the control animals (Fig. 1).

Only a few measurements of fetal arterial plasma progesterone were carried out because of the limited amount of plasma available. The mean preinfusion value in 6 fetuses was $0.65 \pm 0.08 \mathrm{ng} / \mathrm{ml}$ and there was a significant fall to a mean of $0.28 \pm 0.04 \mathrm{ng} / \mathrm{ml}$ after $1 \mathrm{~h}(P<0.01)$ with little subsequent change (Fig. 1).

\section{Effect of epostane on adrenocortical activity}

An immediate fall in both maternal and fetal plasma cortisol was seen following epostane (Fig. 2). In the ewes a $30 \%$ drop in cortisol occurred after $15 \mathrm{~min}$ and the levels remained at $40-50 \%$ of preinfusion values from $30 \mathrm{~min}$ of the start of infusion. There was a marked overshoot the following day at a time when the first stage of labour had generally begun.

In the fetuses the drop in plasma cortisol began at 30-60 min after the start of the epostane infusion irrespective of the basal concentration. In Group 2 in which the final pre-partum surge of 


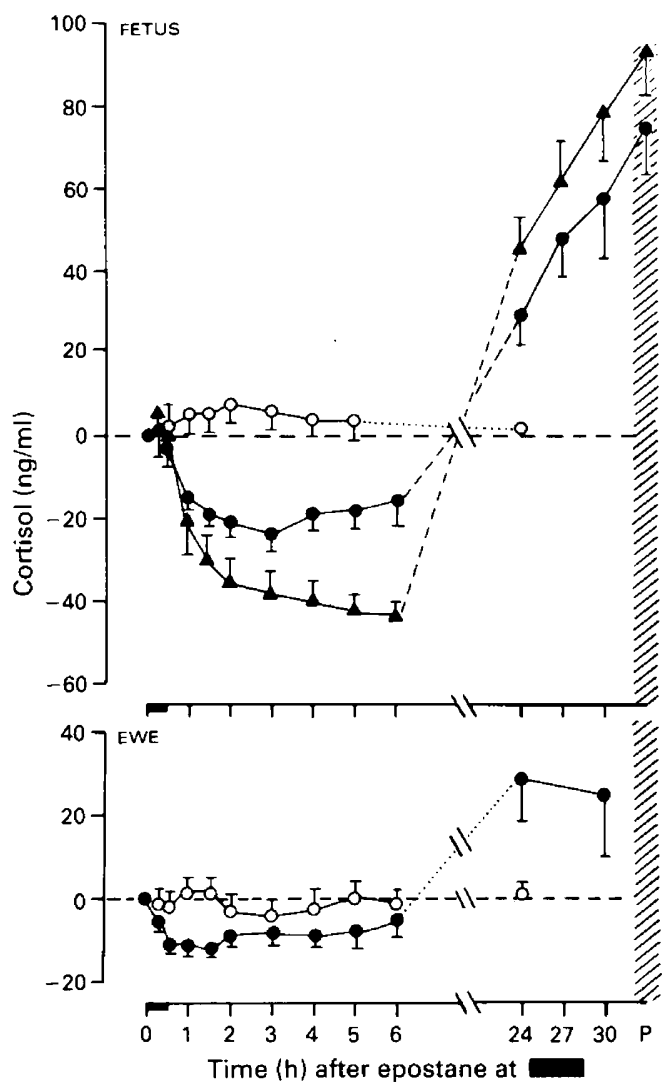

Fig. 2. Mean increment or decrement $( \pm$ s.e.) in arterial plasma cortisol concentration in fetuses and mothers after treatment (horizontal bar) with epostane $(\boldsymbol{O}, \mathbf{\Delta})$ or ethanol $(0)$. $\mathbf{\Delta}$, Fetuses at 140-142 days of gestation $(N=5)$;, fetuses at $137-139$ days of gestation $(N=5)$. Ewes from both groups $(\Theta, N=10)$. Time of parturition $(P)$ is indicated by the hatched area.

cortisol had already begun (141-142 days), the fall was most striking; the resting level was $77 \pm 8.5 \mathrm{ng} / \mathrm{ml}$ and the mean maximum decrement was $43.5 \pm 2.1 \mathrm{ng} / \mathrm{ml}(P<0.01)$. In the younger fetuses (137-139 days) the basal value was $42 \cdot 2 \pm 7 \cdot 6 \mathrm{ng} / \mathrm{ml}$; this fell significantly by $20.4 \pm 5.1 \mathrm{ng} / \mathrm{ml}(P<0.01)$. In one 137-day fetus the pre-partum increase in plasma cortisol had not begun and the epostane-induced fall, from 19 to $10 \mathrm{ng} / \mathrm{ml}$, was within the range of basal values for this age. However, in this and every other fetus tested with epostane, the percentage fall was about $50 \%$ with little further change over the 6-h period. There was an eventual recovery in plasma cortisol concentrations such that an overshoot occurred after $24 \mathrm{~h}$ (Fig. 2), and by the time of delivery fetal plasma cortisol values (mean $149 \pm 13 \mathrm{ng} / \mathrm{ml}, n=10$ ) were within the normal range for parturition at term.

The fall in fetal plasma cortisol after epostane was followed, 30-60 min later, by a large rise in plasma ACTH. The basal plasma cortisol and ACTH concentrations in Group 2 fetuses were $77.0 \pm 8.5 \mathrm{ng} / \mathrm{ml}$ and $79.0 \pm 11.7 \mathrm{pg} / \mathrm{ml}$ respectively; the changes which accompanied the drop in plasma cortisol after epostane in this group are shown in Fig. 3. The 10-12-fold increment in plasma ACTH eventually appeared to overcome the inhibitory effect of the epostane on fetal adrenocortical activity and by $12-24 \mathrm{~h} \mathrm{ACTH}$ concentrations were falling as the fetal cortisol values continued to rise until delivery. 


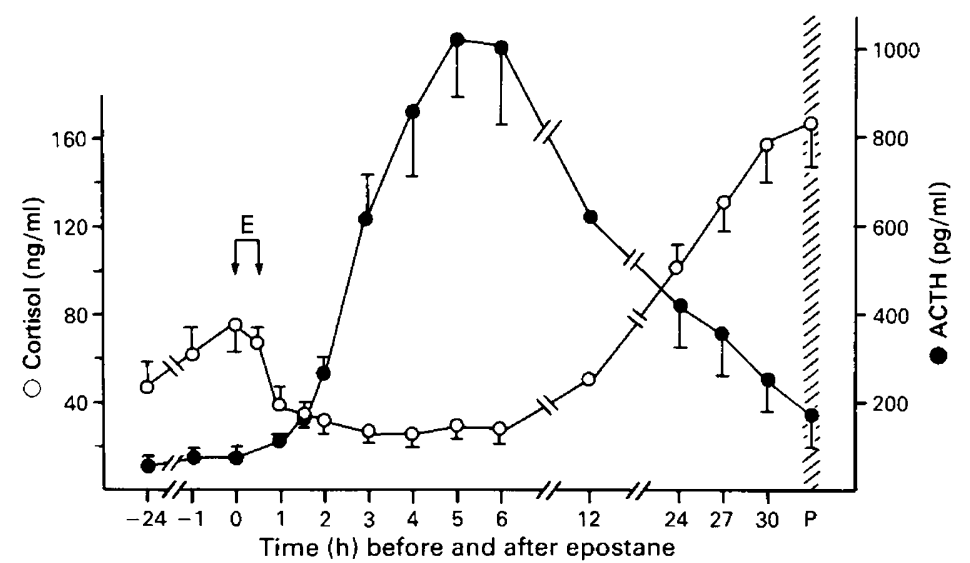

Fig. 3. Mean ( \pm s.e.) fetal plasma cortisol and ACTH before and after epostane treatment (arrows) $(\mathrm{N}=5) . \mathrm{P}=$ time of parturition.

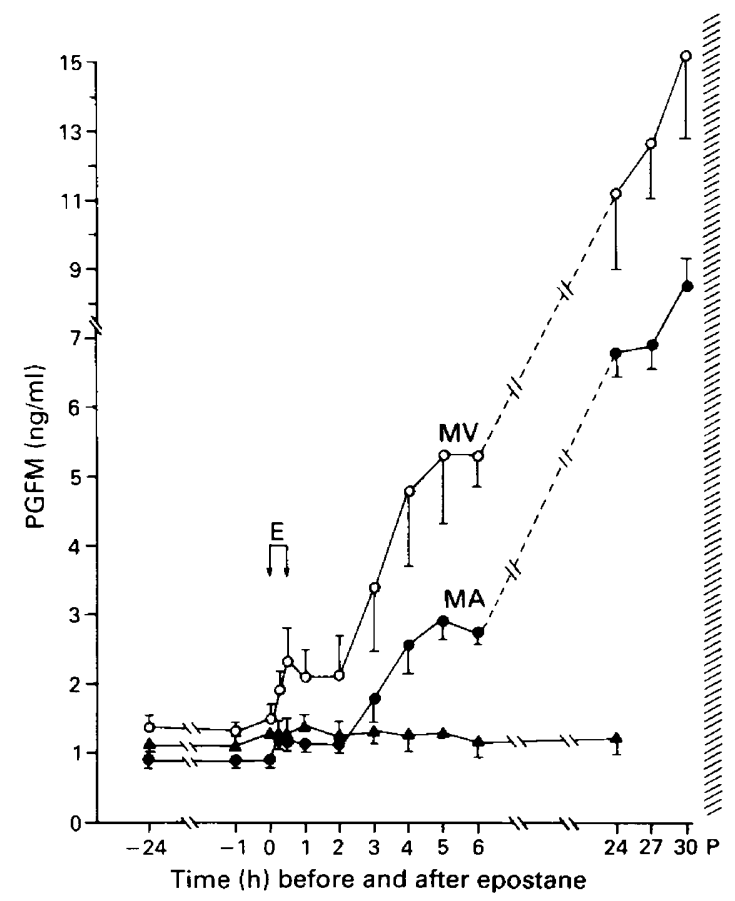

Fig. 4. Mean ( \pm s.e.) maternal arterial $(\odot)$ and uterine venous $(O)$ plasma concentrations of PGFM before and after epostane treatment (arrows) $(\mathrm{N}=5) . \Delta$, Control infusion of ethanol, $(\mathrm{N}=5) . \mathrm{P}=$ time of parturition.

\section{Other hormonal effects of epostane}

Measurements of arterial and uterine venous maternal plasma PGFM were carried out in 5 ewes. A significant increment in uterine venous PGFM of $0.46 \pm 0.12 \mathrm{ng} / \mathrm{ml}(P<0.02, \mathrm{~N}=5)$ occurred $15 \mathrm{~min}$ after the start of infusion (Fig. 4). Concentrations in the vein and artery rose further in the 3-6 $\mathrm{h}$ after epostane and reached values of $6-12 \mathrm{ng} / \mathrm{ml}$ on the day of birth. The mean venous-arterial difference in PGFM concentration increased from $0.49 \pm 0.1$ to $1.36 \pm 0.3 \mathrm{ng} / \mathrm{ml}$ at $60 \mathrm{~min}$ $(P<0.01)$ and to $2.3 \pm 0.3 \mathrm{ng} / \mathrm{ml}$ by $6 \mathrm{~h}(P<0.01)$. 
Table 2. Mean ( \pm s.e.) incidence and duration of myometrial contractures before and after epostane treatment in 7 ewes at 138-141 days of gestation

\begin{tabular}{|c|c|c|c|c|}
\hline \multirow[b]{3}{*}{ Measurements } & \multicolumn{4}{|c|}{ Recording periods } \\
\hline & \multirow{2}{*}{$\begin{array}{c}\text { Day before } \\
\text { test } \\
(4-6 \mathrm{~h})\end{array}$} & \multicolumn{3}{|c|}{ Day of test } \\
\hline & & $\begin{array}{c}1-2 \mathrm{~h} \\
\text { (before epostane) }\end{array}$ & $0-3 \mathrm{~h}$ & $\begin{array}{l}3-6 h \\
\text { postane) }\end{array}$ \\
\hline $\begin{array}{l}\text { No. of contractions } \\
\text { (per h) }\end{array}$ & $1.87 \pm 0.06$ & $1.85 \pm 0.05$ & $1.65 \pm 0.24$ & $2.71 \pm 0.21^{*}$ \\
\hline Duration (min) & $6 \cdot 3 \pm 0 \cdot 3$ & $6 \cdot 3 \pm 0 \cdot 6$ & $6 \cdot 9 \pm 0 \cdot 3$ & $6 \cdot 2 \pm 0.5$ \\
\hline
\end{tabular}

${ }^{*} P<0.05$ compared with value before epostane treatment.

Uterine venous plasma oestradiol- $17 \beta$ concentrations were measured in 6 ewes. The levels fell after epostane treatment from a mean value of $28 \pm 16.7 \mathrm{pg} / \mathrm{ml}$ to $<10 \mathrm{pg} / \mathrm{ml}$ and remained low throughout most of the 6-h period. By $5-6 \mathrm{~h}$ there was a slight rise in 3 of the 6 ewes. There was, however, no consistent increase from pre-infusion levels on the day of delivery: the values ranged from 10 to $100 \mathrm{pg} / \mathrm{ml}$.

\section{Effect of epostane on myometrial activity}

Table 2 shows the incidence of slow myometrial contractions (contractures) per hour and their average length on the day preceding the epostane treatment, together with values on the day of the test. The mean number of contractures per hour increased significantly during the second 3-h period after epostane, but there was no significant change in the duration of each contracture throughout the test period. By $24 \mathrm{~h}$ after epostane the pattern of myometrial activity was closely similar to that seen in spontaneous first-stage labour at term, with small intense bursts of increased pressure occurring at frequent intervals. Second stage had usually begun by $32-34 \mathrm{~h}$ and the recording equipment was then disconnected for the ewe to deliver without disturbance.

\section{Discussion}

The present results show that inhibition of $3 \beta$-HSD in the sheep near term leads to delivery of viable healthy lambs within a predictable period from the time of injection of the drug. Epostane, administered parenterally or orally, would seem to be a safe, reliable inducing agent with no apparent side effects or long term problems. All the ewes tested in this study delivered their placentae and reared their young satisfactorily. Other potential methods of inducing parturition in sheep have considerable drawbacks, particularly on a large scale. Stimulation of the fetal pituitary-adrenal axis directly (Liggins et al., 1973) is reliable but impracticable outside the laboratory. Injection of the ewe with large doses of dexamethazone (Fylling, 1971) will eventually induce labour but the timing is relatively imprecise, while prostaglandins or oxytocin are only effective once labour has begun (Hindson \& Ward, 1973; Liggins et al., 1973; Thorburn \& Challis, 1979).

The rapid sustained drop in maternal plasma progesterone concentrations after epostane confirmed previous observations with trilostane and epostane on pregnant sheep (Taylor et al., 1982; Jenkin \& Thorburn, 1984; Ledger et al., 1985). This persistent inhibition of placental 3 $\beta$-HSD is difficult to explain and is in marked contrast to the action of epostane in two other species. In the sow, in which the source of progesterone is luteal, two types of responses were seen; in the majority of animals $3 \beta$-HSD inhibition resulted in complete luteolysis and progesterone concentrations remained low until delivery, but in others the fall in progesterone was short-lived and did not result in parturition (Silver \& Fowden, 1988). In the mare, in which progesterone is produced by the placenta, high doses of epostane caused only a temporary reduction in circulating progesterone without inducing labour (Fowden \& Silver, 1987). 
The absence of significant changes in maternal plasma oestrogen concentrations in any of the studies on sheep reported so far is perhaps surprising although this can probably be explained by the prolonged reduction in progesterone elicited by trilostane and epostane in this species. The source of oestradiol at the end of gestation in the sheep is placental progesterone which is hydroxylated and aromatized under the influence of increasing fetal plasma cortisol concentrations (Anderson $e t$ al., 1975). These events may still occur to a limited extent after $3 \beta$-HSD inhibition, provided (a) that sufficient progesterone is available for conversion and (b) that sufficient cortisol is produced by the fetus to stimulate the necessary enzyme changes. It may well be that both these criteria are met during $3 \beta$-HSD inhibition in the last 10 days of gestation and that some local increase in maternal oestradiol production is elicited by the rapid rise in fetal plasma cortisol before delivery. On the other hand, earlier in gestation fetal plasma cortisol concentrations may be too low to induce the conversion of any available placental progesterone after epostane. In fact the increase in fetal adrenocortical activity towards term may be the clue to the variations in the efficacy of $3 \beta-\mathrm{HSD}$ inhibition in inducing labour in sheep.

Inhibition of adrenal steroidogenesis by epostane and trilostane, which was first described in monkey and rat (Potts et al., 1978; Schane et al., 1979), and more recently in the pregnant sow and fetuses (Silver \& Fowden, 1988), leads to a temporary depression of circulating corticosteroids in both mother and fetus with a consequent increase in plasma ACTH concentration. In the present study the fetal pituitary response to lowered plasma cortisol was far greater than the normal rise seen just before term (Hennessy et al., 1982). Indeed, the ACTH concentrations attained were comparable with those reported by Wintour et al. (1980) after fetal adrenalectomy and probably represent near maximal fetal pituitary output. However, before about 125-130 days of gestation only minimal amounts of cortisol are being secreted by the fetal adrenal cortex (Barnes et al., 1978; Hennessy et al., 1982) so little or no depression of output would be expected after $3 \beta-H S D$ inhibition. In turn, no ACTH feedback response will be stimulated and no increase in cortisol production would be likely to occur in the following $24 \mathrm{~h}$. Hence the second of the two criteria (that sufficient cortisol be produced to stimulate the requisite placental enzyme changes) will not be fulfilled.

A feature of the rapid drop in circulating progesterone in this and earlier studies was the equally fast increase in maternal plasma PGFM concentration (Taylor et al., 1982; Jenkin \& Thorburn, 1984; Ledger et al., 1985). This raises the question of whether a rise in oestrogen is in fact required for the induction of uterine PGF production in the sheep: a view which is widely held (Liggins et al., 1973; Thorburn \& Challis, 1979). In the present experiments a significant increase in uterine vein PGFM was detected as soon as circulating progesterone had fallen, i.e. $15 \mathrm{~min}$ after injection of epostane. However, this did not result in detectable changes in myometrial activity until $3 \mathrm{~h}$ later, but thereafter the number of slow uterine contractions increased significantly. Ledger et al. (1985) reported an increase in uterine activity $12 \mathrm{~h}$ after the injection of epostane in ewes of 129-136 days of gestation. It is possible that similar changes in uterine motility also occurred in the earlier studies on ewes tested with trilostane since increased plasma PGFM concentrations were seen in these experiments irrespective of the outcome of the pregnancy (Taylor et al., 1982; Jenkin \& Thorburn, 1984).

When premature delivery is induced before 135 days by the infusion of ACTH into the fetus all the necessary maturational events occur in utero and a viable lamb is delivered (Liggins et al., 1973; Liggins, 1976). On the other hand delivery by Caesarean section at a similar age results in a premature lamb whose chances of survival are poor (Jobe \& Ikegama, 1984). In normal circumstances the prepartum rise in fetal plasma cortisol occurs over a period of 10 to 15 days with a final surge in the last 72-96 h (Liggins et al., 1973; Barnes et al., 1978; Hennessy et al., 1982). In the present experiments the initial incremental changes in fetal plasma cortisol had already begun and it is probable that the lambs of Group 2 (basal plasma cortisol, $77 \mathrm{ng} / \mathrm{ml}$ ) would have survived delivery in the absence of any further cortisol increase. However, for those in Group 1 (138-139 days) the 12-18 h pre-partum rise initiated by the ACTH feedback response may well have been crucial to their subsequent survival. Clearly there is little to be gained by inducing labour too prematurely if the necessary maturational changes have not yet been completed. This applies to the pre-partum mammary 
development in the ewe as well as to the final changes in the fetus. The present study shows clearly that between 6 and 10 days before normal term is a safe period for induction of labour in sheep by $3 \beta$ HSD inhibition. At this stage the fetal pituitary-adrenal axis is fully competent, the feedback mechanism ensures that a short pre-partum surge of cortisol occurs, and, perhaps equally important, lactogenesis is also stimulated during this curtailed maturational period.

I thank Mr P. Hughes and Miss T. Grimes for assistance during surgery; Mr D. Clarke and Mr I. Cooper for care of the animals; and Mrs J. Knox, Mr K. Richardson and Miss H. Randall for help with the assays. A supply of epostane was kindly donated by Sterling Winthrop Laboratories, Guildford.

\section{References}

Anderson, A.B.M., Flint, A.P.F. \& Turnbull, A.C. (1975) Mechanisms of action of glucocorticoids in induction of ovine parturition: effect of placental steroid metabolism. J. Endocr. 66, 61-70.

Barnes, R.J., Comline, R.S. \& Silver, M. (1978) Effect of cortisol on liver glycogen concentration in hypophysectomized, adrenalectomized and normal fetal lambs. J. Physiol., Lond. 275, 567-579.

Creange, J.E., Anzalone, A.J., Potts, G.O. \& Schane, H.P. (1981) WIN 32,729. A new, potent interceptive agent in rats and rhesus monkeys. Contraception 24, 289-299.

Comline, R.S. \& Silver, M. (1972) The composition of fetal and maternal blood during parturition in the ewe. J. Physiol., Lond. 260, 571-586.

Fowden, A.L. \& Silver, M. (1983) The effect of the nutritional state on uterine prostaglandin F metabolite concentrations in the pregnant ewe during late gestation. Q. Jlexp. Physiol. 68, 337-349.

Fowden, A.L. \& Silver, M. (1985) The effects of food withdrawal on uterine contractile activity and on plasma cortisol concentrations in ewes and their fetuses during late gestation. In The Physiological Development of the Fetus and Newborn, pp. 157-161. Eds C. T. Jones \& P. W. Nathanielsz. Academic Press, London.

Fowden, A.L. \& Silver, M. (1987) Effects of inhibiting $3 \beta$ hydroxysteroid dehydrogenase on plasma progesterone and other steroids in the pregnant mare near term. J. Reprod. Fert., Suppl. 35, 539-545.

Fylling, P. (1971) Premature parturition following dexamethazone administration to pregnant ewes. Acta endocr., Copenh. 66, 289-295.

Hennessy, D.P., Coghlan, J.P., Hardy, R.J. \& Wintour, E.M. (1982) Development of the pituitary-adrenal axis in chronically catheterized ovine fetuses. $J$. devl. Physiol. 4, 339-352.

Hindson, J.C. \& Ward, W.R. (1973) Myometrial studies in the pregnant sheep. In The Endocrinology of Pregnancy and Parturition, pp. 153-163. Ed. C. Pierrepoint. Alpha-Omega, Cardiff.

Jenkin, G. \& Thorburn, G.D. (1984) Inhibition of progesterone secretion by a $3 \beta$-hydroxysteroid dehydrogenase inhibitor in late pregnant sheep. Can. J. Physiol. Pharm. 63, 136-142.

Jobe, A. \& Ikegama, M. (1984) The prematurely delivered lamb as a model for studies of neonatal adaptation. In Arimals Models in Fetal Medicine III, pp. 4-31. Ed. P. W. Nathanielsz. Perinatology Press, Ithaca.
Ledger, W.L., Webster, M.A., Anderson, A.B.M. \& Turnbull, A.C. (1985) Effect of inhibition of prostaglandin synthesis on cervical softening and uterine activity during ovine parturition resulting from progesterone withdrawal induced by epostane. J. Endocr. 105, 227-233.

Liggins, G.C. (1976) Adrenocortical-related maturational events in the fetus. Am. J. Obstet. Gynec. 126, 931-935.

Liggins, G.C., Fairclough, R.J., Grieve, S.A., Kendall, J.Z. \& Knox, B.S. (1973) The mechanism of initiation of parturition in the ewe. Recent Prog. Horm. Res. 29, 111-150.

Potts, G.O., Creange, J.E., Harding, H.R. \& Schane, H.P. (1978) Trilostane, an orally active inhibitor of steroid biosynthesis. Steroids 32, No. 2, 257-267.

Robinson, P.M., Comline, R.S., Fowden, A.L. \& Silver, M. (1983) Adrenal cortex of fetal lamb: changes after hypophysectomy and effects of synacthen on cytoarchitecture and secretory activity. Q.Jl exp. Physiol. 68, 15-27.

Schane, H.P., Potts, G.O. \& Creange, J.E. (1979) Inhibition of ovarian placenta and adrenal steroidogenesis in the rhesus monkey by trilostane. Fert. Steril. 32, $464-467$.

Silver, M. (1981) An assessment of the chronically catheterized fetal preparation in sheep and other species. Placenta, Suppl. 2, 89-108.

Silver, M. (1988) Successful induction of labour in sheep. Vet. Rec. 120, 299-300.

Silver, M. \& Fowden, A.L. (1988) Inhibition of 3 3 hydroxysteroid dehydrogenase in the sow near term: effect on fetal and maternal steroids and on delivery. $Q$.Jl exp. Physiol. (in press).

Snedecor, G.W. \& Cochrane, W.G. (1967) Statistical Methods, 5th edn. Iowa State Press, Ames.

Taylor, M.J., Webb, R., Mitchell, M.D. \& Robinson, J.S. (1982) Effect of progesterone withdrawal in sheep during late pregnancy. J. Endocr. 92, 85-93.

Thorburn, G.D. \& Challis, J.R.G. (1979) Endocrine control of parturition. Physiol. Rev. 59, 863-917.

Wintour, E.M., Coghlan, J.P., Hardy, K.H., Hennessy, D.P., Lingwood, B.E. \& Scoggins, B.A. (1980) Adrenal corticosteroids and immunoreactive ACTH in chronically cannulated ovine fetuses with bilateral adrenalectomy. Acta endocr., Copenh. 95, 546-552.

Received 6 April 1987 